\title{
ON THE HYERS-ULAM STABILITY OF APPROXIMATELY PEXIDER MAPPINGS
}

\section{Bouikhalene Belaid, Elqorachi Elhoucien and Themistocles M. Rassias}

Abstract. In this paper we investigate the Hyers-Ulam stability of the Pexider functional equation

$$
f_{1}(x+y)+f_{2}(x+\sigma(y))=f_{3}(x)+f_{4}(y), \quad x, y \in E,
$$

where $E$ is a normed space and $\sigma: E \longrightarrow E$ is an involution.

Mathematics subject classification (2000): 39B52, 39B82,.

Key words and phrases: quadratic equation, Pexider equation, Hyers-Ulam-Rassias stability.

\section{REFERENCES}

[1] ACZÉL J., The general solution of two functional equations by reduction to functions additive in two variables and with the aid of Hamel bases, Glasnik Mat.-Fiz Astronom. Ser. II Društvo Mat. Fiz. Hrvatske, 20 (1965), 65-73.

[2] Bouikhalene B. Elqorachi E. And Rassias Th. M., On the generalized Hyers-Ulam stability of the quadratic functional equation with a general involution, (Submitted).

[3] CHolewa P. W., Remarks on the stability of functional equations, Aequationes Math. 27 (1984), 76-86.

[4] CzERwIK S., On the stability of the quadratic mapping in normed spaces, Abh. Math. Sem. Univ. Hamburg, 62 (1992), 59-64.

[5] FORTI G. L., Hyers-Ulam stability of functional equations in several variables, Aequationes Math. 50 (1995), 143-190.

[6] GAJDA Z., On stability of additive mappings, Internat. J. Math. Sci. 14 (1991), 431-434.

[7] GǍVRUTA, A generalization of the Hyers-Ulam-Rassias stability of approximately additive mappings, J. Math. Anal. Appl. 184 (1994), 431-436.

[8] HYERS D. H., On the stability of the linear functional equation, Proc. Nat. Acad. Sci. U.S.A. 27 (1941), 222-224.

[9] Hyers D. H. AND RASSias TH. M., Approximate homomorphisms, Aequationes Math., 44 (1992), $125-153$.

[10] Hyers D. H., IsAC, G. I. AND RASSIAS Th. M., Stability of Functional Equations in Several Variables, Birkhäuser, Basel, 1998.

[11] JUN K.-W. AND LEE Y.-H., A generalization of the Hyers-Ulam-Rassias stability of Jensen's equation, J. Math. Anal. Appl. 238 (1999), 305-315.

[12] JUNG S.-M., Hyers-Ulam-Rassias Stability of Functional Equations in Mathematical Analysis, Hadronic Press, Inc., Palm Harbor, Florida, 2003.

[13] Jung S.-M., Stability of the quadratic equation of Pexider type, Abh. Math. Sem. Univ. Hamburg, 70 (2000), 175-190.

[14] JUNG S.-M., SAHOO P. K., Hyers-Ulam stability of the quadratic equation of Pexider type, J. Korean Math. Soc., 38 (2001), No. 3, 645-656.

[15] Jung S.-M., SAHOO P. K., Stability of a functional equation of Drygas, Aequationes Math. 64 (2002), No. 3, 263-273.

[16] PARK C.-G., On the stability of the linear mapping in Banach modules, J. Math. Anal. Appl. 275 (2002), 711-720. 
[17] Rassias TH. M., On the stability of linear mapping in Banach spaces, Proc. Amer. Math. Soc. 72 (1978), 297-300.

[18] RASSIAS TH. M., The problem of S. M. Ulam for approximately multiplicative mappings, J. Math. Anal. Appl. 246 (2000), 352-378.

[19] RASSIAS TH. M., On the stability of the functional equations and a problem of Ulam, Acta Applicandae Mathematicae. 62 (2000), 23-130.

[20] RASSIAS TH. M. AND SEMRL, P., On the behavior of mappings which do not satisfy Hyers-Ulam stability, Proc. Amer. Math. Soc. 114 (1992), 989-993.

[21] RASSIAS TH. M. AND TABOR J., Stability of Mappings of Hyers-Ulam Type, Hardronic Press, Inc., Palm Harbor, Florida 1994.

[22] SKOF F., Local properties and approximations of operators, Rend. Sem. Math. Fis. Milano 53 (1983), 113-129.

[23] STETKÆR, H., Functional equations on abelian groups with involution, Aequationes Math. 54 (1997), 144-172.

[24] Ulam S. M., A Collection of Mathematical Problems, Interscience Publ. New York, 1961. Problems in Modern Mathematics, Wiley, New York 1964.

[25] LEE Y.-H. AND JUN K.-W., A note on the Hyers-Ulam-Rassias stability of Pexider equation, J. Korean Math. Soc. 37 (2000), No. 1, 111-124. 